PRAKTISCHES BIBELLEXIKON. Unter Mitarbeit katholischer und evangelischer Theologen, herausgegeben von Anton GRABNER-HAIDER, Freiburg-Basel-Wien 1977 (2 wyd.).

W wydawnictwie Herder ukazało się już 2 wydanie Praktisches Bibellexikon (= PBL, 1 wyd. 1969), jako owoc współpracy 56 telogów katolickich (40) i ewangelickich (16) pod kierunkiem hermeneuty austriackiego A. Grabner-Haider. Z tej racji PBL zasługuje na miano ek umeniczne go. PBL jest pomyślany jako słownik i jako podręcznik. Jako słownik obejmuje a) realia biblijne i b) pojęcia biblijno-teologiczne. Jako podręcznik analizuje w porządku alfabetycznym 3 grupy pojęć: a) pojęcia historycznoredakcyjne, b) pojęcia historycznoreligijne (albo religioznawcze) i c) pojęcia hermeneutyczne. O ile dwie pierwsze grupy pojęć mogą być dokładne i wyraźnie wyodrębnione, o tyle trzecia grupa - pojęcia hermeneutyczne - może budzić pewne zastrzeżenia co do kryterium wyboru hasłowego. Ale w poszukiwaniach nie ma rzeczy doskonałych. Godne uwagi są tzw. klucze do Starego i Nowego Test., polegające na streszczeniu tematycznym ksiąg biblijnych oraz pomysłowa tablica chronologiczna, uwzględniająca obok wydarzeń historii biblijnej i świeckiej chronologię powstawania pism biblijnych.

Kraków

KS. JERZY CHMIEL

\title{
WYDAWNICTWA POLSKIEGO TOWARZYSTWA TEOLOGICZNEGO W KRAKOWIE
}

N O W O Ś Ć

\section{TEOLOGIA NAUKĄ O BOGU}

IV Kongres Teologów Polskich

Kraków-Mogiła 14-16 IX 1976

redakcja

ks. M. Jaworski - ks. A. Kubiś

stron $421+$ wklejki fot.

cena $200 \mathrm{zl}$ 